\title{
SYSTEMATIC REVISION OF THE GENERA OF PANGASIIDAE (SILURIFORMES, OSTARIOPHYSI)
}

\author{
Rudhy Gustiano*) and Laurent Pouyaud ${ }^{* *}$
}

\begin{abstract}
The family Pangasiidae belongs to the suborder Siluroidei, order Siluriformes, and suborder Ostariophysi. Since the groups were established as Pangasiini Bleeker, 1858; its content and classification have been greatly changed. Judging from the literature, the main constraint to cultivate wild species and to optimize the production of cultured species is needed to the poorly documented systematics of this family. Therefore the objective of the present study is to provide the diagnostic characters and the keys for identification the genera of Pangasiidae. The results clearly demonstrate that biometrically four natural groups can be distinguished. They are the genus Helicophagus, Pangasianodon, Pteropangasius, and Pangasius. The diagnosis of the family, the identification key of the genera and the description are given.
\end{abstract}

KEYWORDS: taxonomy, biometrics, catfish, Pangasiidae, Helicophagus, Pangasianodon, Pteropangasius, Pangasius

\section{INTRODUCTION}

Related to taxonomy, the typology species concept using biometric characterization, although sometimes considered "classical", is still a powerful method to determine different taxa. In many cases, biometrics is very useful to segregate different taxa in the field. During the past 20 years, various biometric analyses have been applied on many catfish families and fish in general to provide correct diagnoses of taxa and keys (Teugels, 1986; De Vos, 1995; Retzer \& Page, 1997; Reis, 1997; Armbruster, 1998; Ng \& Ng, 1998).

Smith (1945) recognised four genera in the Pangasiidae; they are Helicophagus Bleeker, 1858; Pangasius Valenciennes, 1840; Pteropangasius Fowler, 1937; Pangasianodon Chevey, 1930. Roberts \& Vidthayanon (1991) in a systematic revision of Pangasiidae, recognised two genera: Helicophagus Bleeker, 1858 with two valid species and Pangasius
Valenciennes, 1840 with 19 valid species. Recently, seven new species were added to the genus Pangasius (Pouyaud et al., 1999; Roberts, 1999; Pouyaud \& Teugels, 2000; Pouyaud et al., 2002; Gustiano et al., 2003) and another one was described in the genus Helicophagus ( $\mathrm{Ng} \&$ Kottelat, 2000). Following Vidthayanon \& Roongthongbaisuree (1993), Pangasius consists of four subgenera: (1) Pangasius (Pangasianodon) Chevey, 1930 diagnosed by the absence of mandibular barbels, the absence of teeth in adults and the presence of a single swimbladder, and including $P$. hypophthalmus Sauvage, 1878 and $P$. gigas Chevey, 1930; (2) Pangasius (Pteropangasius) Fowler, 1937 with four lobes in the swimbladder and with multiple segments in the last lobe and consisting of $P$. pleurotaenia Sauvage, 1878 and $P$. micronemus Bleeker, 1847; (3) Pangasius (Neopangasius) Popta, 1904 with palatal teeth arranged in a single large patch, high vertebral

* Research Institute for Freshwater Aquaculture, Bogor, Indonesia

**) Institut de Recherches pour le Dévelopment (IRD), Indonesia - France 
counts and containing P. nieuwenhuisii Popta, 1904, P. humeralis Roberts, 1989, P. lithostoma Roberts, 1989, P. kinabatanganensis Roberts \& Vidthayanon, 1991; and (4) Pangasius (Pangasius) Valenciennes, 1840 for which no diagnostic features are provided and which includes all remaining species. Molecular phylogenies published by Pouyaud et al. (2000) confirm the subgeneric classification proposed for Pangasius except for Pangasius (Neopangasius) which is polyphyletic and which should be included in Pangasius (Pangasius). Gustiano (2003) raised the subgenera proposed by Pouyaud et al. (2000) based on osteological analysis.

In this study, it presents the results of a biometrical analysis of Pangasiidae genera in order to provide the diagnostic characters and the key for identification of the genera.

\section{MATERIALS AND METHODS}

Nine hundred and ninety nine specimens, collected during the "Catfish Asia" project (Legendre, 1999), formed the core of the material examined during this study. The material from all other examined specimens was sampled in Bangladesh, India, Vietnam, Cambodia, Laos, Thailand, Malaysia, and Indonesia. Additional material including the types of previously described genera housed in various museums was also examined.

On each specimen, 35 point to point measurements covering the possible variation of the body conformation were taken using dial callipers as follows: standard length (SL) from tip of snout to caudal peduncle; head length (HL) from tip of snout to posterior border of operculum; snout length (SNL) from tip of snout to anterior eye border; anterior snout width (SNW1) taken between the anterior nostrils; the posterior snout width (SNW2) taken between posterior nostrils; head depth (HD) taken at the level of the posterior eye border; head width (HW) inter-orbital length taken on frontal part of the head; predorsal distance (PDL) from tip of snout to base of first dorsal spine; caudal peduncle length (CPL) from base of last anal fin ray to middle of caudal peduncle; caudal peduncle depth (CPD) taken as minimum body depth; pectoral spine length (PESL) from its base to its tip; pectoral fin length (PEFL) from pectoral spine base to tip of fin; dorsal spine length (DSP) from base of first dorsal spine to tip; dorsal fin length (DFL) from base of first dorsal spine to tip of fin; pelvic fin length (PFL) from base to tip of fin; anal fin height (AFH) from base of first anal fin ray to tip of longest ray; anal fin length (AFL) from base of first ray to base of last anal ray; adipose fin height (ADFH) from base to tip; maximal adipose fin width (ADFW); maximal orbital diameter (ED); mouth width (WM); lower jaw length (LJL) from tip of snout to corner of mouth; interorbital distance (WT) taken between the eyes; distance snout to isthmus (DSI) from tip of snout to isthmus with a closed mouth; postocular length $(\mathrm{OL})$ from posterior border of eye to posterior border of operculum; maxillary barbel length (MBL); mandibular barbel length (MABL); body width (BW) from left to right scapular excrescence bones close to pectoral spine base; prepectoral length (PPEL) from tip of snout to pectoral spine base; prepelvic length (PPL) from tip of snout to first pelvic fin ray base; vomerine width (VMW); vomerine length (VML); palatine length (PAL); palatine width (PAW); dorsal spine width (DSW) taken at base of second dorsal spine. The following meristic counts were noted: number of gill rakers on the first branchial arch, number of dorsal, pelvic, pectoral and anal fin rays. An illustration of the measured characters is shown in Gustiano (2003) and Gustiano \& Pouyaud (2007).

\section{Genera Characterization}

Data were subjected to principal component analysis (PCA) (Bookstein et al., 1985) using the CSS Statistica package (Stat Soft, Inc.), version 4.5 in order to define structuring characters. For this purpose, measurements were log-transformed in order to minimise the effect of non-normality before the PCA was run on the covariance matrix. The first factor, considered as the size-factor was not taken into account, in order to minimise the effect of size differences between the samples. Allometry is indicate by unequal loadings of variable on the first component, and biological interpretation of allometric data proceed using coefficients of the first components against the second components that was linear. Missing data were casewise deleted. An independent PCA was run on the correlation matrix from the untransformed count data. Finally, data analysis consisted in characterising groups from scatter plots between pairs of structuring characters for subsequent use in generic identification keys.

\section{RESULTS AND DISCUSSIONS}

Based on the analysis of 35 measured and five counted characters, the diagnosis of the 
family, the identification key of the genera, and the description are given below.

\section{Pangasiidae}

Morphologically, pangasiid catfishes are recognized by a laterally compressed body, the presence of two pairs of barbels (one pair of maxillary and one pair of mandibular), the relatively long anal fin, and short dorsal fin with two spines (first small and hidden under the skin), adipose fin small with free posterior margin.

The first step of the analysis is to define how many natural groups can be recognised in the Pangasiidae. A PCA using the covariance matrix for 27 measurements on the 657 specimens results in two groups (Figure 1). The first group is entirely isolated on the negative sector of PCIV and the sector of PCV, while the second group is mostly located on the right of the first group and it has a lower score on the PCV. The factor loadings (Table 1) show that the components of PCIV are dominated by the size of the vomerine toothplate (length and width), the mandibular and maxillary barbel length, the anterior and posterior width of snout, the adipose fin height, the width of mouth, and the anal fin length. The components of PCV are dominated by the eye diameter, the adipose fin width, the postopercular length, the distance snout to isthmus, the predorsal length and the dorsal spine width. The first group includes the type species of the genus Helicophagus Bleeker, 1858 (type Helicophagus typus Bleeker, 1858b). The second group contains the other species. Further analysis using the dominant characters showed that the first group differs from the remaining group by the combination of a slender anterior snout $(<16.5 \% \mathrm{HL})$ and a predorsal length of $34.5 \%-40.5 \% \mathrm{SL}$ (Figure 2).

When plotting the PCII and PCIV (Figure 3) derived from a PCA on 27 variables taken on 657 specimens, we can distinguish one group entirely situated on the negative sector of PC II and only slightly overlapping on PC II with the other specimens. This group includes the type species of the Pangasius (Pteropangasius) Fowler, 1937 (type Pteropangasius cultratus, Smith, 1931) and Pseudolais Vaillant, 1902 (type Pseudolais tetranema Vaillant, 1902). Pseudolais was considered a junior synonym of Pangasius

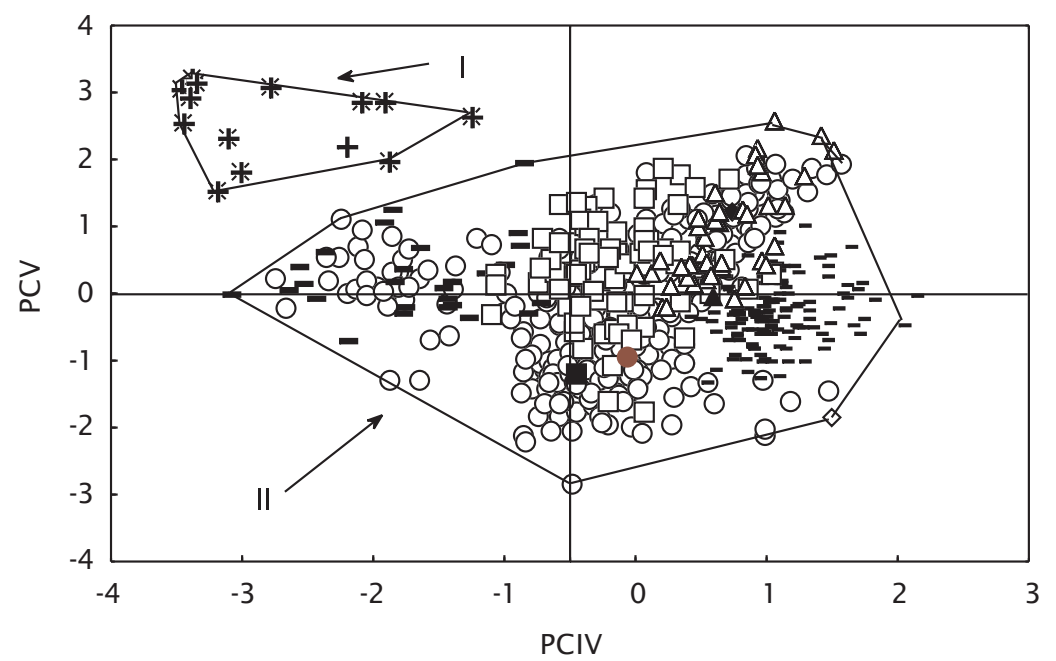

Figure 1. Plot of PCIV versus PCV taken from a PCA of log-transformed 27 metric variables on 657 specimens. Group I including type species of genus Helicophagus and group II including other type species of remaining genera. + type species of Helicophagus Bleeker, 1858; * species of Helicophagus; type species of Pteropangasius Fowler, 1937; type species of Pseudolais Vaillant, 1902; $\square$ species of Pteropangasius; _ species of Pangasianodon; $\bullet$ type species of Pangasius Valenciennes, 1840; t species of Pangasius; $\boldsymbol{\Delta}$ type species of Neopangasius Popta, 1904; $\triangle$ species of Neopangasius; s type species of Pseudopangasius Bleeker, 1862; - species of Pseudopangasius 
Table 1. Fourth and fifth factor score coefficients for the morphometric PCA using 27 log-transformed variables taken on 657 specimens

\begin{tabular}{lrrrr}
\hline \multicolumn{1}{c}{ Charact ers } & PCII & PCIII & PCIV & PCV \\
\hline Log standard length & -0.192051 & -0.127963 & -0.040700 & 0.090990 \\
Log head length & 0.006009 & 0.076897 & -0.065557 & 0.080169 \\
Log snout length & 0.054124 & 0.095031 & -0.007069 & -0.045073 \\
Log anterior width of snout & -0.044065 & 0.125431 & 0.146888 & -0.114664 \\
Log posterior width of snout & -0.114329 & 0.022214 & 0.102023 & -0.058984 \\
Log head depth & -0.154080 & 0.011534 & -0.041098 & -0.021370 \\
Log head width & -0.060144 & 0.075084 & 0.037954 & -0.093172 \\
Log predorsal length & -0.022953 & 0.069133 & -0.090078 & 0.132110 \\
Log caudal peduncle length & -0.298312 & -0.211069 & 0.028959 & 0.065055 \\
Log caudal peduncle depth & -0.282056 & -0.180328 & -0.091380 & 0.040146 \\
Log anal fin length & -0.304946 & -0.288269 & -0.108781 & 0.096374 \\
Log adifose fin height & 0.180955 & 0.114387 & 0.136576 & -0.109974 \\
Log adipose fin width & 0.283461 & 0.225239 & -0.136965 & -0.242571 \\
Log eye diameter & -0.644339 & -0.300840 & -0.174826 & -0.289090 \\
Log width of mouth & 0.014831 & 0.171115 & 0.119613 & -0.084397 \\
Log lower jaw length & 0.033771 & 0.157285 & 0.078729 & 0.110161 \\
Log interorbital distance & 0.087351 & 0.118568 & 0.074973 & -0.053529 \\
Log distance snout to isthmus & -0.069396 & -0.003745 & -0.028172 & 0.141315 \\
Log opercular length & 0.099410 & 0.126030 & -0.054615 & 0.228444 \\
Log maxillary barbel length & 0.525420 & -0.525527 & -0.111332 & -0.066876 \\
Log mandibular barbel length & 0.744845 & -0.286005 & -0.250088 & -0.030094 \\
Log body width & -0.031793 & 0.052811 & 0.038109 & 0.034386 \\
Log prepectoral length & -0.003412 & 0.058176 & -0.055020 & 0.076971 \\
Log prepelvic length & -0.075364 & 0.030684 & -0.030694 & 0.072204 \\
Log vomerine width & 0.172729 & 0.062083 & 0.217694 & -0.034455 \\
Log vomerine length & 0.208900 & -0.380418 & 0.600940 & 0.009903 \\
Log dorsal spine width & 0.249905 & 0.147002 & -0.080841 & 0.117502 \\
\hline
\end{tabular}

by Roberts \& Vidthayanon (1991). The dominant scores for the second factor are mandibular and maxillary barbel length, eye diameter, anal fin length, depth and length of caudal peduncle, and adipose fin width (Table 1). Moreover, the isolated group can be distinguished by a short maxillary barbel length $(<192 \%$ ED) (Figure 4).

A plot of the third principal component of a PCA of 27 metric variables ( $n=657$ specimens) (PCIII) against the first principal component from a PCA of five meristic characters (PCMI) taken on 657 specimens distinguished another group (Figure 5). The dominant characters for PCIII are maxillary and mandibular barbel length, vomerine toothplate length, eye diameter, and anal fin length (Table 1). The dominant meristic characters (PCMI) separating this group is: num- ber of pectoral fin rays, and pelvic fin rays (Table 2). Detailed analysis of meristic characters revealed that the character separating this group from the remaining specimens is the number of pelvic fin rays which is more than seven in the isolated group while the number is less than seven in the remaining specimens. No existing type species falls into the isolated group. However, we consider that the group belongs to the subgenus Pangasius (Pangasianodon) Chevey, 1930 (type Pangasianodon gigas Chevey, 1930). Chevey (1930) did not designate a type specimen when he established Pangasianodon. The only specimen for which he gave the length was one of almost 2 meters, which he saw in August 1930 (see also Smith, 1945). The detailed measurements that accompany his original description of Pangasianodon gigas are taken from a model 


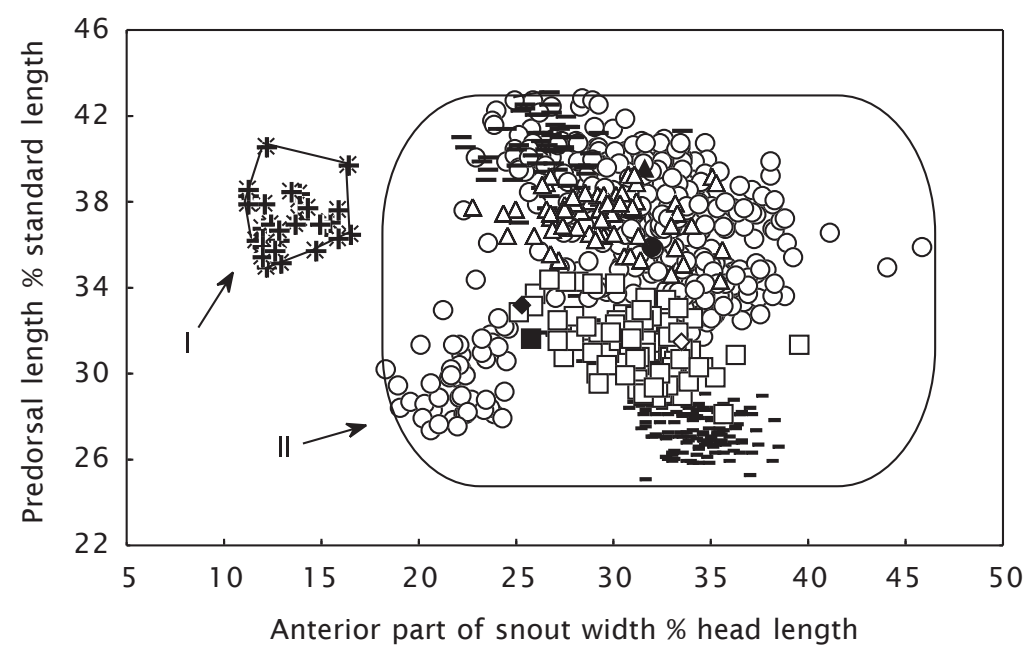

Figure 2. Plot of anterior part of snout width (\% $\mathrm{HL})$ and predorsal length $(\% \mathrm{SL})$. Group I includes type species of genus Helicophagus and group 2 including other type species of remaining genera. + type species of Helicophagus Bleeker, 1858; * species of Helicophagus; - type species of Pteropangasius Fowler, 1937; type species of Pseudolais Vaillant, 1902; $\square$ species of Pteropangasius; _ species of Pangasianodon; - type species of Pangasius Valenciennes, 1840; t species of Pangasius; $\boldsymbol{\Delta}$ type species of Neopangasius Popta, 1904; $\triangle$ species of Neopangasius; s type species of Pseudopangasius Bleeker, 1862; - species of Pseudopangasius

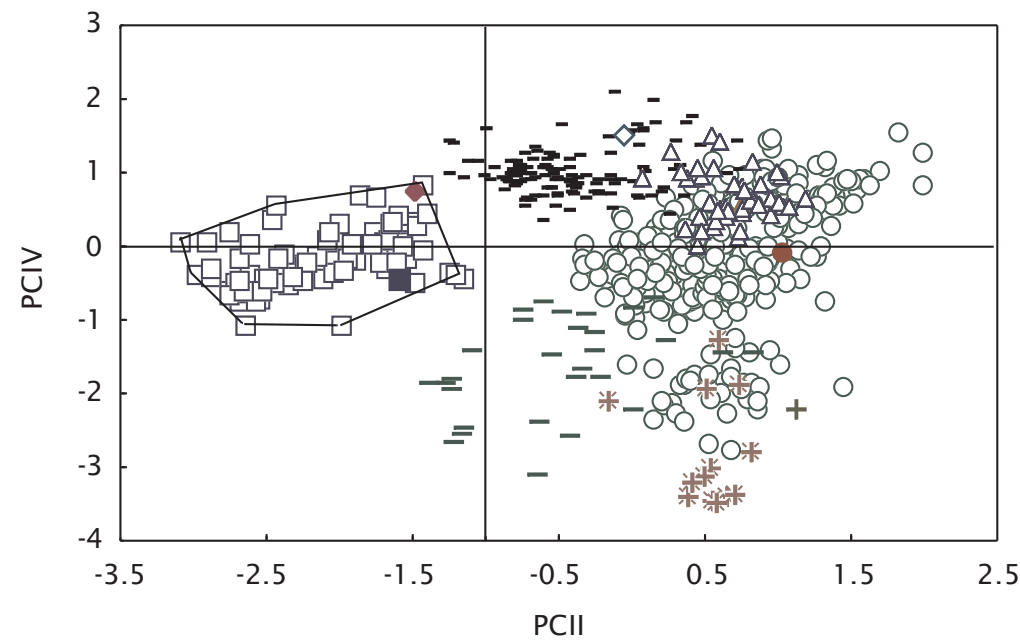

Figure 3. Plot of PCII versus PCIV taken from a PCA of log-transformed 27 metric variables on 657 specimens. The isolated group includes type species of the genus Pteropangasius Fowler, 1937 and Pseudolasis Vaillant, 1902. The remaining group includes other type species. + type species of Helicophagus Bleeker, 1858; * species of Helicophagus; - type species of Pteropangasius Fowler, 1937; type species of Pseudolais Vaillant, 1902; $\square$ species of Pteropangasius; _ species of Pangasianodon; $\bullet$ type species of Pangasius Valenciennes, 1840; t species of Pangasius; $\Delta$ type species of Neopangasius Popta, 1904; $\triangle$ species of Neopangasius; s type species of Pseudopangasius Bleeker, 1862; - species of Pseudopangasius 


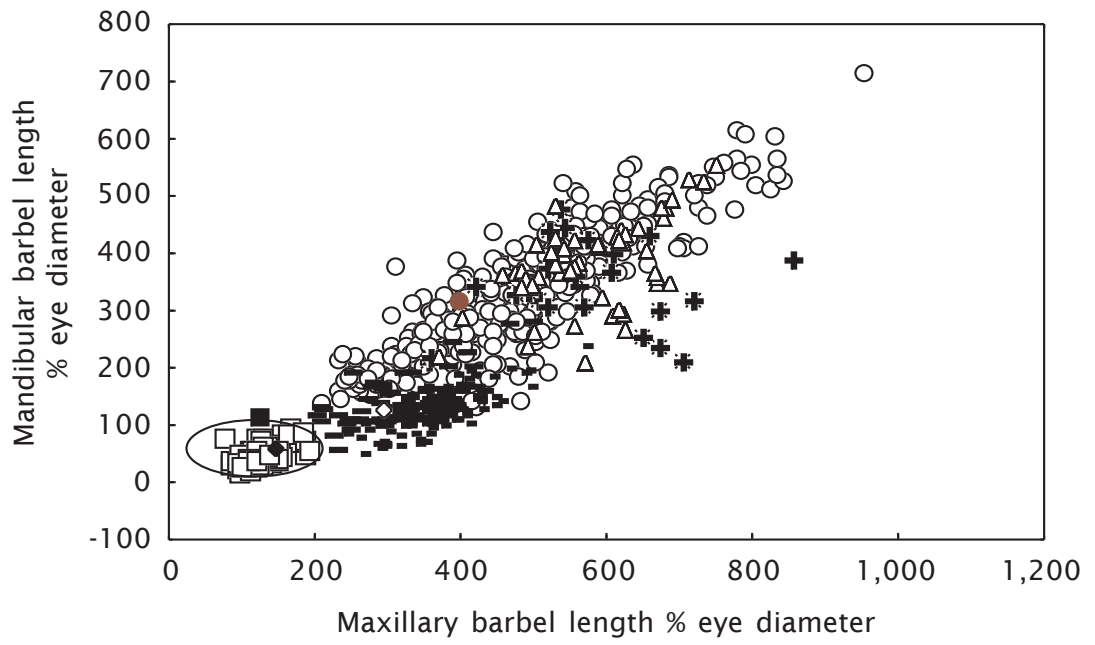

Figure 4. Plot of maxillary barbel length (\% ED) and mandibular barbel length (\% ED). The isolated group includes type species of genus Pteropangasius Fowler, 1937 and Pseudolais Vaillant, 1902. The remaining group includes other type species. + type species of Helicophagus Bleeker, 1858; * species of Helicophagus; - type species of Pteropangasius Fowler, 1937; type species of Pseudolais Vaillant, 1902; $\square$ species of Pteropangasius; _ species of Pangasianodon; type species of Pangasius Valenciennes, 1840; t species of Pangasius; $\boldsymbol{\Delta}$ type species of Neopangasius Popta, 1904; $\triangle$ species of Neopangasius; s type species of Pseudopangasius Bleeker, 1862; - species of Pseudopangasius

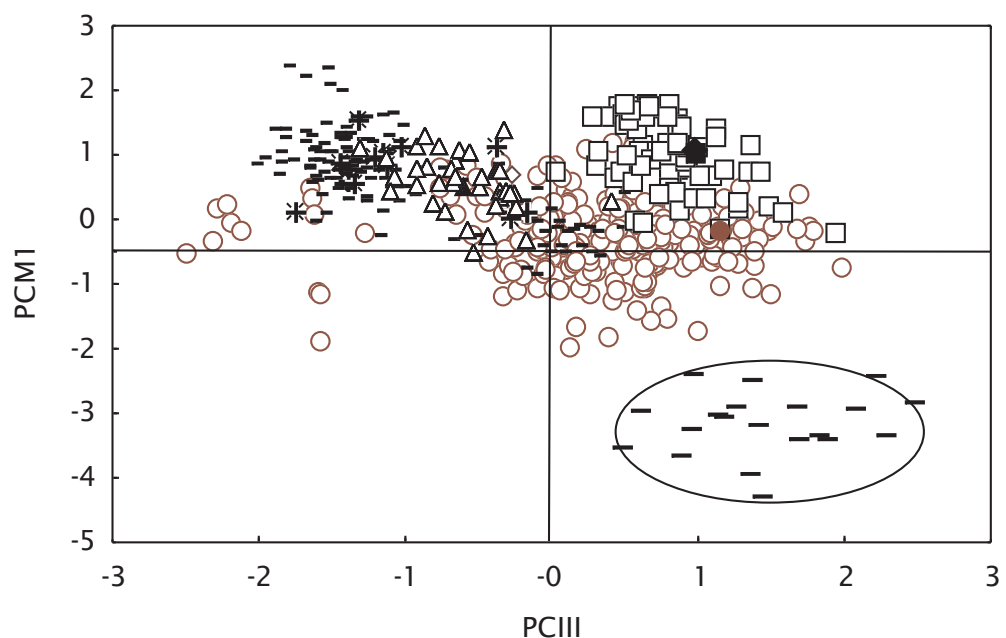

Figure 5. Plot of PCIII taken from a PCA of 27 log-transformed variables ( $n=657$ specimens) versus PMI taken from a PCA of five meristic counts on 657 specimens. Isolated group including all specimens of Pangasianodon. The remaining group including other type species. + type species of Helicophagus Bleeker, 1858; * species of Helicophagus; - type species of Pteropangasius Fowler, 1937; type species of Pseudolais Vaillant, 1902; $\square$ species of Pteropangasius; _ species of Pangasianodon; $\bullet$ type species of Pangasius Valenciennes, 1840; t species of Pangasius; $\Delta$ type species of Neopangasius Popta, 1904; $\triangle$ species of Neopangasius; s type species of Pseudopangasius Bleeker, 1862; - species of Pseudopangasius 
Table 2. First factor score coefficient for the meristic PCA using five counts taken on 657 specimens

\begin{tabular}{lr}
\hline \multicolumn{1}{c}{ Characters } & \multicolumn{1}{c}{ PCMI } \\
\hline Gill raker & 0.355267 \\
Dorsal fin ray & -0.276082 \\
Pectoral ray & -0.725470 \\
Pelvic fin ray & 0.682432 \\
Anal fin ray & -0.444639 \\
\hline
\end{tabular}

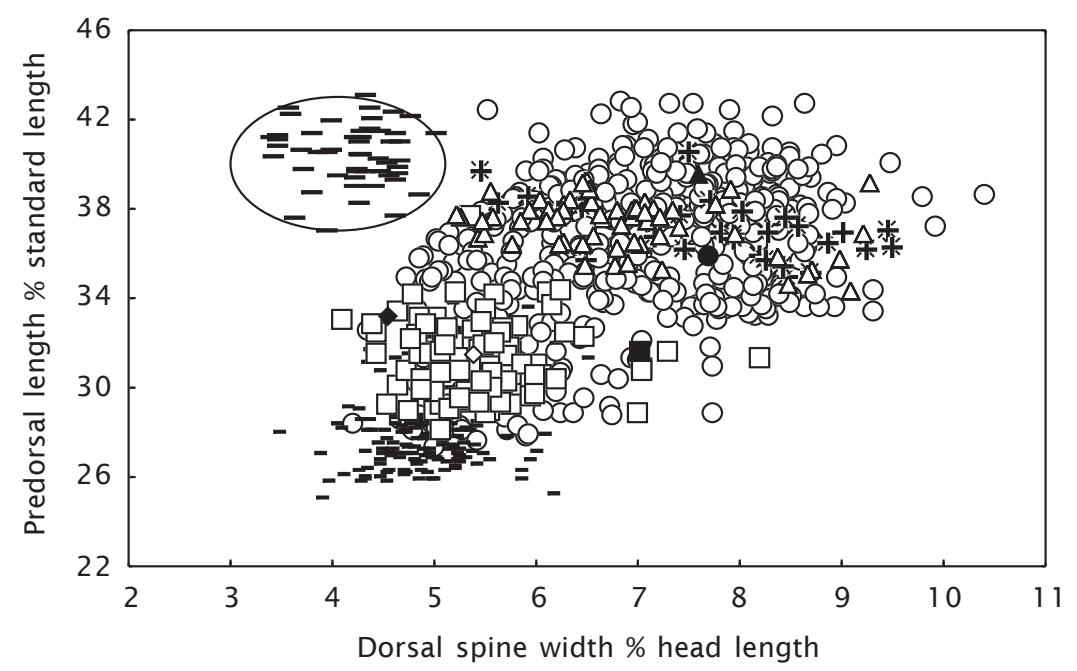

Figure 6. Plot of the dorsal spine length (\% SL) and predorsal length (\% SL). Isolated group including all specimens of Pangasianodon. The remaining group including other type species. + type species of Helicophagus Bleeker, 1858; * species of Helicophagus; type species of Pteropangasius Fowler, 1937; type species of Pseudolais Vaillant, 1902; $\square$ species of Pteropangasius; _ species of Pangasianodon; - type species of Pangasius Valenciennes, 1840; t species of Pangasius; $\boldsymbol{\Delta}$ type species of Neopangasius Popta, 1904; $\triangle$ species of Neopangasius; s type species of Pseudopangasius Bleeker, 1862; - species of Pseudopangasius

of fish, 2.5 meters long, in the Economic Museum of Cambodia (Smith, 1945). Thereafter, analysis of the dominant characters showed that the isolated group is separated from others in having a long predorsal length (37\%$43.2 \% \mathrm{SL})$ and a slender dorsal spine $(2.8 \%-5 \%$ $\mathrm{HL}$ ) (Figure 6).

Further PCA analysis did not enable to divide the remaining specimens and available known types [Neopangasius Popta, 1904 (type Neopangasius nieuwenhuisii, 1904); Pseudopangasius Bleeker, 1862 (type Pseudopangasius polyuranodon Bleeker, 1862); Pangasius Valenciennes, 1840 [(type, Pangasius pangasius (Hamilton, 1822)] into iso- lated groups. In this analysis, we were not able to examine the validity of Sinopangasius Chang $\&$ Wu, 1965 (type Sinopangasius semicultratus Chang \& Wu, 1965). The type of Sinopangasius, ASIZB 56-1 174, is deposited in the Institute of Zoology Academia Sinica Beijing, China. Roberts \& Vidthayanon (1991) put this genus together with Pangasius Valenciennes, 1840.

Our results clearly demonstrate that biometrically four natural groups can be distinguished. They are the genus Helicophagus and three of four species complexes previously recognized as subgenera and, or species groups in the genus Pangasius by previous worker. 


\section{Key to Genera}

1a. 8-9 pelvic fin rays, long predorsal length $(>37 \% \mathrm{SL})$, and slender dorsal spine width $(3.5 \%-5 \% \mathrm{HL})$ Pangasianodon

1b. 6 pelvic fin rays .2

2 a. Slender anterior part of snout $(<16.5 \% \mathrm{HL})$, posterior nostrils are in between anterior nostrils and orbit. Helicophagus

2b. Robust anterior part of snout (>16.5\% HL), posterior nostrils close behind anterior ones and above imaginary line from anterior nostrils and orbit .......................... 3

3a. Eye relatively large, minute maxillary barbel $(<192 \% E D)$, dorsal and pectoral fins relatively thin, pectoral fin with minute and numerous serrations on the anterior and posterior edge of the fin, and minute adipose fin Pteropangasius

3 b. Eye varies from small to large, relatively long maxillary barbel (>192\% ED), dorsal and pectoral fins robust, and adipose fin relatively robust... Pangasius

Below, the different genera are presented. For each genus, a key is given. This is followed by a detailed description for each genus recognized as valid.

\section{Helicophagus Bleeker, 1858}

Helicophagus Bleeker, 1858b: 45 (type species Helicophagus typus Bleeker, 1858, by monotypy); Günther, 1864: 64; Weber \& De Beaufort, 1913: 251; Hardenberg, 1948:412; Burgess, 1989: 105; Roberts \& Vidthayanon, 1991: 138; Kottelat et al., 1993: 100; Rainboth, 1996: 152.

Diagnosis: this genus differs from all other pangasiid genera by a short and a large premaxillary toothplate; a narrow mouth $(<35 \% \mathrm{HL})$; the front border of the snout is pierced by anterior nostrils; a slender anterior part of snout length $(<16.5 \% \mathrm{HL})$; a short and a large premaxillary toothplate; the posterior nostrils are between and in line with the anterior nostrils and the middle of eye; the vomerine toothplate without additional toothplate.

\section{Pangasianodon Chevey, 1930}

Pangasianodon Chevey, 1930: 536, Fig. 1, 2 (type Pangasianodon gigas Chevey, 1930; no type designated); Smith, 1945: 372; Rainboth, 1996: 153.

Pangasius (Pangasianodon) Roberts \&
Vidthayanon, 1991: 102; Vidthayanon, 1993: 160.

Diagnosis: distinguished from the other genera by eight or nine pelvic fin rays; long predorsal length $(>37 \% \mathrm{SL})$; slender dorsal spine width $(3.5 \%-5 \% \mathrm{HL})$; vomerine toothplate thin and disappears in the larger size; mandibular barbels disappear ontogenetically; terminal mouth, with teeth of upper jaw entirely covered by lower jaw when mouth is closed.

\section{Pteropangasius Fowler, 1937}

Pteropangasius Fowler, 1937: 142 (type Pteropangasius cultratus Smith, 1931; by monotypy); Smith, 1945: 369.

Diagnosis: this genus is distinguished from other genera by minute maxillary barbels $(<192 \% \mathrm{ED})$, dorsal and pectoral fin relatively thin, pectoral fin with numerous minute serrations on the anterior and posterior edge of the spine, minute adipose fin, and eye relatively large.

\section{Pangasius Valenciennes, 1840}

Pangasius Cuvier \& Valenciennes, 1840: 45; Günther, 1864: 61; Weber \& De Beaufort, 1913: 254; Smith, 1945: Jayaram, 1977: 26; 357; Burgess, 1989: 105; Roberts, 1989: 131; Roberts \& Vidthayanon, 1991: 112; Kottelat et al., 1993: 100; Rainboth, 1996: 154.

Diagnosis: six pelvic fin rays, short predorsal length $(<37 \%)$, and robust dorsal spine width $(>5 \% \mathrm{HL})$, robust anterior part of snout length $(>16.5 \% \mathrm{HL})$, posterior nostrils close behind anterior ones and above imaginary line from anterior nostril and orbit, long and slender premaxillary toothplate, eye varies from small to large, relatively long barbel length (>192\% ED), dorsal and pectoral fin robust, and adipose fin relatively robust.

\section{CONCLUSION}

Four natural groups can be distinguished. They are the genus Helicophagus with slender anterior part of snout $(<16.5 \% \mathrm{HL})$, posterior nostrils are in between anterior nostrils are in between anterior nostril and orbit. Pangasianodon has $8-9$ pelvic fin rays, long predorsal length $(>37 \% \mathrm{SL})$, and slender dorsal spine width $(3.5 \%-5 \% \mathrm{HL})$. Pteropangasius has eye relatively large, minute maxillary barbel $(<192 \% \mathrm{ED})$, dorsal and pectoral fins relatively thin, pectoral fin with minute and numerous serrations on the anterior and posterior edge 
of the fin, and minute adipose fin. Pangasius has eye varies from small to large, relatively long barbel (>192\% ED), dorsal and pectoral fin robust, and adipose fin relatively robust,

\section{ACKNOWLEDGEMENT}

The author thanks to the people who work together in the Catfish Project for their help in collecting fish samples. I am also grateful to AARD for the fellowship to complete this study through "PAATP" Project at Leuven University, Belgium. This paper forms part of the INCO.DC PROJECT "Catfish Asia" financed by the European Union (contract IC 18-CT 96-0043).

\section{REFERENCES}

Armbruster, J.W. 1998. Review of the loricariid catfish genus Aphanotorulus and redescription of $A$. unicolor (Teleostei: Siluriformes). Ichthyol. Explor. Freshwaters. 8: 253-262.

Bleeker, P. 1847. Nieuwe bijdrage tot de kennis der Siluroiden van Java. Verh. Batav. Genootsch. 21:1-12.

Bleeker, P. 1858. Ichthyologiae Arcipelago Indici Prodromus. Vol. I. Siluri. Lange \& Co., Batavia, Nederland-Ind. 370 pp.

Bookstein, F.L., B. Chernoff, R. Elder, J. Humphries, G. Smith, and R. Strauss. 1985. Morphometrics in evolutionary biology. The geometry of size and shape change, with examples from fishes. Acad. Nat. Sci., Philad., Spec. Publ. 15: 1-277.

Burgess, W.E. 1989. An atlas of freshwater and marine catfishes. A preliminary survey of the Siluriformes. T.F.H. Publication, Neptune City, NJ, USA. 784 pp.

Chevey, P. 1930. Sur un nouveau silure géant du bassin du Mékong Pangasianodon gigas nov. g., nov. sp. Bull. Soc. Zool. Fr. 55: 536-542.

De Vos, L. 1995. A systematic revision of the African Schilbeidae (Teleostei: Siluriformes). Ann. Mus. Afr. Centr. 271: 1450.

Fowler, H.E. 1937. Zoological results of the third de Schauensee Siamese Expedition, Part 8. Fishes obtained in 1936. Proc. Acad. Nat. Sci. Philad. 89: 125-264.

Gustiano, R. 2003. Taxonomy and phylogeny of Pangasiidae catfishes from Asia. Ph.D. Thesis. Leuven University, Belgium. 296 pp.

Gustiano, R., G.G. Teugels, and L. Pouyaud. 2003. Revision of the Pangasius kunyit catfish complex, with description of two new species from South East, Asia (Siluriformes, Pangasiidae). J. Nat. Hist. 37: 357-376.

Gustiano, R. and L. Pouyaud. 2007.

Günther, A. 1864. Catalog of the Physostomi containing families Siluridae, Characinidae, Haplochitonidae, Sternoptychidae, Scopelidae in the collection of the British Museum, London. $455 \mathrm{pp}$.

Hardenberg, J.D.F. 1948. Some new or rare fishes of the Indo-australian Archipelago. Treubia 19: 407-415.

Jayaram, K.C. 1977. Aid to the identification of Siluroids 2: Siluroidae, Schilbeidae, Pangasidae, Amblycipitidae, Akysidae. Rec. Zool. Surv. India Occ. Pap. 10: 1-33.

Kottelat, M., A.J. Whitten, S.R. Kartikasari, and S. Woerjoatmodjo. 1993. Freshwater fishes of Western Indonesia and Sulawesi. Periplus edition Ltd, Hongkong. 293 pp.

Legendre, M. 1999. The catfish Asia project: Backgrounds, aims and prospects. In: The biological diversity and aquaculture of Clariid and Pangasiid Catfish in Southeast Asia. Proc. mid-term workshop of the "Catfish Asia project" (Editors: M. Legendre and A. Pariselle), IRD, Paris. p. 7-14.

Ng, H.H. and P.K.L. Ng. 1998. A revision of the South-east Asian catfish genus Silurichthys. J. Fish Biol. 52: 291-333.

$\mathrm{Ng}, \mathrm{H} . \mathrm{H}$ and M. Kottelat. 2000. Helicophagus leptorhyncus, a new species of molluscivorous catfish from Indochina (Teleostei, Pangasiidae). Raffles Bull. Zool. 48: 55-58.

Popta, C.L.M. 1904. Descriptions préliminaire des nouvelles especèces de poisons recueillies au Borneo Central par M. Le. Dr. A.W. Nieuwenhuis en 1898 et 1900. Not. Leiden Mus. 24: 179-181.

Pouyaud, L and G.G. Teugels. 2000. Description of a new pangasiid catfish from East Kalimantan, Indonesia. Ichthyol. Explor. Freshwater. 11: 193-200.

Pouyaud, L., G.G. Teugels, R. Gustiano, and M. Legendre. 2000. Contribution to phylogeny of pangasiid catfishes based on allozymes and mitochondrial DNA. J. Fish Biol. 56: 1,509-1,538.

Pouyaud, L., R. Gustiano, and G.G. Teugels. 2002. Systematic revision of Pangasius polyuranodon complex (Siluriformes, Pangasiidae) with description two new species. Cybium. 26: 243-252. 
Rainboth, W.J. 1996. Fishes of the Cambodian Mekong. FAO species identification field guide for fishery purposes. Rome, FAO. 265 pp.

Roberts, T.R. 1989. The freshwater fishes of Western Borneo (Kalimantan Barat, Indonesia). Mem. Cal. Sci. 14: 1-210.

Roberts, T.R. and C. Vidthayanon. 1991. Systematic revision of the Asian catfish family Pangasiidae, with biological observation and description of three new species. Proc. Acad. Nat. Sci. Philad. 143: 97-144.

Roberts, T.R. 1999. Pangasius bedado, a new species of molluscivorous catfish from Sumatra (Pisces, Siluriformes, Pangasiidae). Nat. Hist. Siam Soc. 47: 109-115.

Reis, R.E. 1997. Revision of the neotropical catfish genus Hoplosternum (Ostariophysi: Siluriformes: Callichthyidae), with the description of two new genera and three new species. Ichthyol. Explor. Freshwaters. 7: 299-326.

Retzer, M.E. and L.M. Page, 1997. Systematics of the stick catfishes, Farlowella Eigenmann \& Eigenmann, 1889. (Pisces, Loricariidae). Proc. Acad. Nat. Sci. Philad. 147: 33-88.
Sauvage, H.E.. 1878. Note sur quelques poisons de'especès nouvelles provenant de eaux douces de I'Indo-Chine. Bull. Soc. Philom. Paris, Ser. 7(2): 233-242.

Smith, H.M. 1945. The freshwater fishes of Siam or Thailand. Bull. U.S. Natl. Mus. 188: 1622.

Teugels, G.G. 1996. Taxonomy, phylogeny and biogeography of catfishes (Ostariophysi, Siluroidei): An overview. Aquat. Living Resour. 9: 9-34.

Valenciennes, A. 1840. Histoire naturelle des poisons. Strasbourg, France. 15: 1-540.

Vidthayanon, C. 1993. Taxonomic revision of the catfish family Pangasiidae. Ph.D. Thesis. Tokyo University of Fisheries. 203 pp.

Vidthayanon, C. and S. Roongthongbaisuree. 1993. Taxonomy of Thai riverine catfishes family Schilbeidae and Pangasiidae. Nat.Inland. fish. Dept. Fish. Tech. Pap. 150: 1-57. (in Thai with English abstract).

Weber, M. and L.F. de Beaufort. 1913. The fishes of Indo-Australian Archipelago II, Malacopterygii, Myctophoidea, Ostariophysi: I. Siluroidea. E.J. Brill Ltd., Leiden. 404 pp. 